NASA/TM-2006-214424

\title{
Update on Extended Operation of Stirling Convertors in Thermal Vacuum at NASA Glenn Research Center
}

Salvatore M. Oriti

Glenn Research Center, Cleveland, Ohio 


\section{NASA STI Program . . . in Profile}

Since its founding, NASA has been dedicated to the advancement of aeronautics and space science. The NASA Scientific and Technical Information (STI) program plays a key part in helping NASA maintain this important role.

The NASA STI Program operates under the auspices of the Agency Chief Information Officer. It collects, organizes, provides for archiving, and disseminates NASA's STI. The NASA STI program provides access to the NASA Aeronautics and Space Database and its public interface, the NASA Technical Reports Server, thus providing one of the largest collections of aeronautical and space science STI in the world. Results are published in both non-NASA channels and by NASA in the NASA STI Report Series, which includes the following report types:

- TECHNICAL PUBLICATION. Reports of completed research or a major significant phase of research that present the results of NASA programs and include extensive data or theoretical analysis. Includes compilations of significant scientific and technical data and information deemed to be of continuing reference value. NASA counterpart of peer-reviewed formal professional papers but has less stringent limitations on manuscript length and extent of graphic presentations.

- TECHNICAL MEMORANDUM. Scientific and technical findings that are preliminary or of specialized interest, e.g., quick release reports, working papers, and bibliographies that contain minimal annotation. Does not contain extensive analysis.

- CONTRACTOR REPORT. Scientific and technical findings by NASA-sponsored contractors and grantees.
- CONFERENCE PUBLICATION. Collected papers from scientific and technical conferences, symposia, seminars, or other meetings sponsored or cosponsored by NASA.

- SPECIAL PUBLICATION. Scientific, technical, or historical information from NASA programs, projects, and missions, often concerned with subjects having substantial public interest.

- TECHNICAL TRANSLATION. Englishlanguage translations of foreign scientific and technical material pertinent to NASA's mission.

Specialized services also include creating custom thesauri, building customized databases, organizing and publishing research results.

For more information about the NASA STI program, see the following:

- Access the NASA STI program home page at http://www.sti.nasa.gov

- E-mail your question via the Internet to help@sti.nasa.gov

- Fax your question to the NASA STI Help Desk at 301-621-0134

- Telephone the NASA STI Help Desk at 301-621-0390

- Write to:

NASA STI Help Desk

NASA Center for AeroSpace Information 7121 Standard Drive Hanover, MD 21076-1320 
NASA/TM-2006-214424

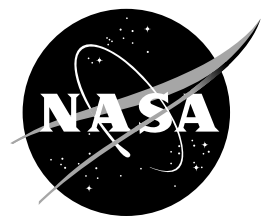

\section{Update on Extended Operation of Stirling Convertors in Thermal Vacuum at NASA Glenn Research Center}

Salvatore M. Oriti

Glenn Research Center, Cleveland, Ohio

Prepared for the

Fourth International Energy Conversion Engineering Conference and Exhibit (IECEC) sponsored by the American Institute of Aeronautics and Astronautics San Diego, California, June 26-29, 2006

National Aeronautics and

Space Administration

Glenn Research Center

Cleveland, Ohio 44135 


\section{Acknowledgments}

The work described in this paper was performed for the Science Mission Directorate (SMD) and the Radioisotope Power System (RPS) Program, which provided funding for these projects.

Trade names and trademarks are used in this report for identification only. Their usage does not constitute an official endorsement, either expressed or implied, by the National Aeronautics and Space Administration.

Level of Review: This material has been technically reviewed by technical management.

Available from

NASA Center for Aerospace Information 7121 Standard Drive

Hanover, MD 21076-1320
National Technical Information Service 5285 Port Royal Road Springfield, VA 22161 


\title{
Update on Extended Operation of Stirling Convertors in Thermal Vacuum at NASA Glenn Research Center
}

\author{
Salvatore M. Oriti \\ National Aeronautics and Space Administration \\ Glenn Research Center \\ Cleveland, Ohio 44135
}

\begin{abstract}
The U.S. Department of Energy (DOE), Lockheed Martin Space Systems (LMSS), Infinia Corporation, and NASA Glenn Research Center (GRC) have been developing a Stirling Radioisotope Generator (SRG) for use as a power system on space science missions. This generator would make use of Stirling cycle energy conversion to achieve higher efficiency than currently used alternatives. A test has been initiated at GRC to demonstrate functionality of Stirling conversion in a thermal vacuum environment over an extended period of time. The test article resembles the configuration of the SRG, but was designed without the requirement of low mass. Throughout the 8700 cumulative hours of operation, modifications to the supporting hardware were required to attain the desired operating conditions. These modifications, the status of testing, and the data recorded will be discussed in this paper.
\end{abstract}

\section{Nomenclature}

$\begin{array}{ll}\text { DOE } & \text { Department of Energy } \\ \text { GPHS } & \text { General Purpose Heat Source } \\ \text { GRC } & \text { Glenn Research Center } \\ \text { LMSS } & \text { Lockheed Martin Space Systems } \\ \text { LN }_{2} & \text { liquid nitrogen } \\ \text { PID } & \text { proportional integral derivative } \\ \text { psig } & \text { pounds per square inch, gauge } \\ \text { RTG } & \text { Radioisotope Thermoelectric Generator } \\ \text { SRG } & \text { Stirling Radioisotope Generator } \\ \text { TDC } & \text { Technology Demonstration Convertor } \\ \mathrm{W}_{\mathrm{e}} & \text { Watt electric } \\ \mathrm{W}_{\text {th }} & \text { Watt thermal }\end{array}$

\section{Introduction}

Lockheed Martin Space Systems (LMSS) has been contracted by the Department of Energy (DOE) to develop a radioisotope-powered generator for potential use on future space science missions (ref. 1). The generator would use two Stirling cycle machines to convert thermal energy from General Purpose Heat Source (GPHS) modules into electrical power, and was thus named the Stirling Radioisotope Generator (SRG). The SRG has potential for multimission applications including Mars, lunar, and deep space. The SRG offers the potential for higher efficiency than Radioisotope Thermoelectric Generators (RTGs) reducing the required amount of radioisotope by a factor of 4. LMSS's design of a 110- $\mathrm{W}_{\mathrm{e}}$ SRG is shown in figure 1 . The design consists of two Stirling convertors each being supplied heat by one GPHS module. The power convertors used in the SRG in figure 1 were designed and manufactured by Infinia, Corporation of Kennewick, Washington. The convertor was designated the Technology Demonstration Convertor (TDC) while being developed under contract to DOE (ref. 2) and has been further developed by Infinia, Corporation under subcontract to LMSS.

NASA Glenn Research Center (GRC) has been supporting LMSS's development of the SRG (ref. 3). Exploration missions that may utilize the SRG could involve continuous operation of the generator for upwards of 14 years. One of the ongoing experiments at GRC consists of two TDCs operating continuously in a thermal vacuum environment. This experiment has several purposes. It provides data for extended operation of the convertors over thousands of hours to examine potential aging effects that would degrade the electrical power generation ability. Some potential sources of aging include high-temperature material creep, alternator magnet degradation, working fluid contamination from internal component outgassing or external impurity permeation, and mechanical wear of moving components. The experiment provides data to validate the various thermal models that were developed during the design of the test article's heat input and rejection systems, which are described later. It also provides data 


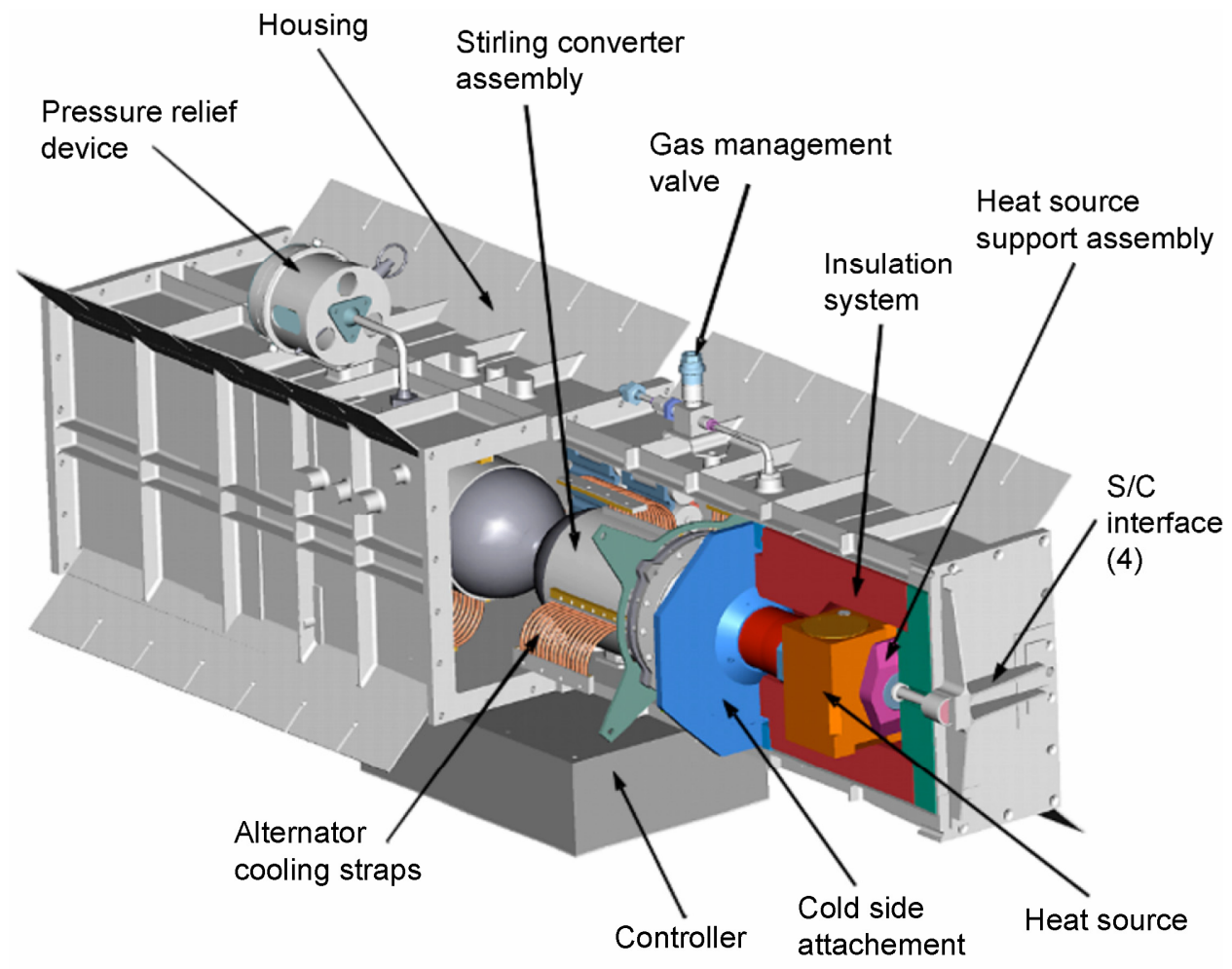

Figure 1.-A $110 \mathrm{~W}_{\mathrm{e}}$ SGR design by LMSS.

for the convertors operating in a thermal environment similar to the SRG. The thermal vacuum configuration more closely emulated the thermal interfaces of a flight system than typical in-air setups previously implemented at GRC (ref. 3). In-air setups have used cartridge heaters bonded to the hot-end of the convertor for heat input and a water jacket on the rejection end for cooling. In a flight system, the heat input interface would be made to a GPHS module, while the heat rejection interface would be coupled to a radiator. The test article was designed with these interfaces in mind as described in the following section.

\section{Test Article Setup}

The experiment makes use of a vacuum chamber to simulate the vacuum of space, and a liquid nitrogen $\left(\mathrm{LN}_{2}\right)$ cold shroud to simulate spacelike sink temperatures. The test article consists of two Stirling TDCs (5 and 6 ) mounted in the dual-opposed configuration. This means that the two convertors are rigidly attached through their mounting flanges and their alternator sections are oriented toward the center as shown in figure 2. Heat is supplied via an electric heater coupled to a heat collector (fig. 3(a)). The heat source is a Boralectric ${ }^{\mathrm{TM}}$ heater, composed of a pyrolytic graphite trace encapsulated by pyrolytic boron nitride acting as an electrical insulator. The heat collector is a cup-shaped component machined from nickel 201 that directs the thermal energy from the rectangular heater to the circumferential heat input zone of the TDC. The Boralectric (GE Advanced Ceramics) heater is held against the heat collector face by a plate. Heat is rejected from the Stirling cycle via a flange attached to radiation panels. The radiation panels dissipate the waste heat to the $\mathrm{LN}_{2}$ shroud surrounding the entire test article. The heat rejection flange is an assembly of nickel and copper sections (fig. 3(b)). The nickel section was brazed to the heat rejection zone of the TDC heater head. Four triangular copper sections were assembled onto each nickel section to increase the effective thermal conductivity of the flange. The copper pieces also form the four flat sides to which the radiation panels attach. T-gon 800 thermal interface material was used between the contacting surfaces. This material is a 0.005 -in.-thick graphite sheet that helps reduce thermal contact resistance. The radiation panels were fabricated out of an aluminum sheet and coated with ECP-2200 to increase surface emissivity. The hot-end and regenerator sections were insulated by Min-K 1302, a machinable ceramic insulation. ANSYS thermal models of the support hardware were constructed for design purposes. The heat collector geometry was optimized using a twodimensional, axisymmetric, parametric thermal model. The heat rejection flange was optimized using a parametric thermal model to determine the nickel and copper section thicknesses. The radiator panel geometry was determined 


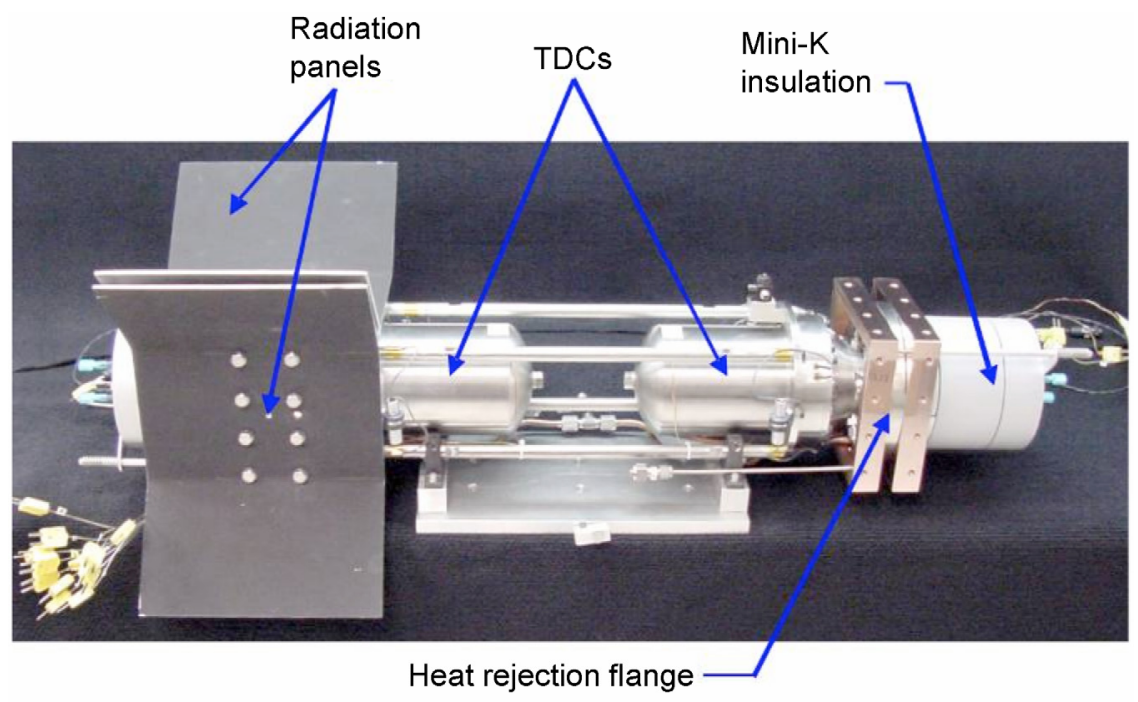

Figure 2.-TDCs 5 and 6 in thermal vacuum configuration.
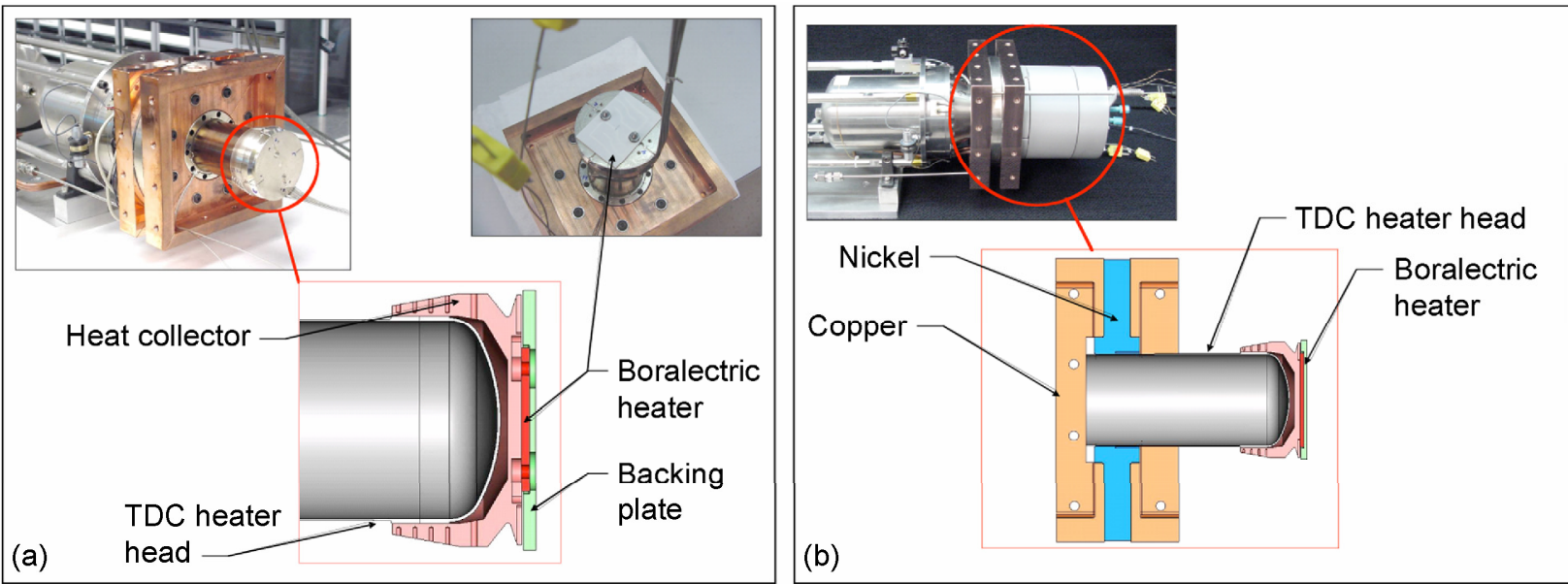

Figure 3.-(a) Heat input hardware. (b) Heat rejection hardware.

using a three-dimensional thermal model. The intent of these designs was to permit operation of the convertors at the nominal conditions of $650{ }^{\circ} \mathrm{C}$ maximum hot-end temperature, $80^{\circ} \mathrm{C}$ rejection temperature, $220 \mathrm{~W}_{\text {th }}$ net heat input, $65 \mathrm{~W}_{\mathrm{e}}$ power output, and 6.0-mm piston amplitude.

\section{Hardware Improvements}

TDCs 5 and 6 have been operating in a thermal vacuum environment since November 2004. Several deficiencies in the initial test article build became apparent that prevented operation at the nominal conditions. Steps were taken to remedy these deficiencies, as described in the following sections.

\section{A. Pressure vessel cooling}

The initial test article build included no specific provision for cooling the pressure vessel other than inherent radiation from the as-machined stainless steel surface of the pressure vessel to the $\mathrm{LN}_{2}$ shroud. This was found to be insufficient and prevented operation of the convertors at design power and temperature. The initial operating point was limited to a hot-end temperature of $513{ }^{\circ} \mathrm{C}$ and $53 \mathrm{~W}_{\mathrm{e}}$ output. At this condition, the pressure vessel temperature was operating at $70^{\circ} \mathrm{C}$, close to the imposed limit of $75^{\circ} \mathrm{C}$. The pressure vessel heat load originates from both the inefficiency of the alternator ( $11 \mathrm{~W}_{\text {th }}$ at full output power) and the thermal coupling to the convertor rejection zone. The only path of heat rejection from the pressure vessel was radiation from the surface to the $\mathrm{LN}_{2}$ shroud. To reduce the pressure vessel surface temperature and enable higher power operation, the surface emissivity was increased by 
adding a layer of Kapton tape. The emissivity of bare stainless steel was measured at 0.15 while stainless steel with a layer of 0.0025 -in.-thick Kapton tape was measured at 0.83; approximately 5.4 times higher. Using these values, analysis was performed to estimate the effect of adding Kapton tape to the pressure vessel surface. The analysis suggested that increasing just 10 percent of the surface's emissivity by a factor of 5.4 would reduce the temperature from 70 to $50^{\circ} \mathrm{C}$; a reduction of $20^{\circ} \mathrm{C}$. However, when this idea was implemented, the pressure vessel temperature was only reduced by $5^{\circ} \mathrm{C}$. In light of this result, the remaining accessible area of the pressure vessel was covered with the Kapton tape layer as shown in figure 4, which resulted in a $13{ }^{\circ} \mathrm{C}$ drop. The addition of Kapton to the majority of the pressure vessel surface permitted operation at the desired conditions. At an average hot-end temperature of $630^{\circ} \mathrm{C}$ and a power output of over $60 \mathrm{~W}_{\mathrm{e}}$ per convertor, the pressure vessel temperature was maintained slightly below $60^{\circ} \mathrm{C}$.

\section{B. Rejection zone cooling}

During initial extended operation, the rejection temperature reached its design point of $80{ }^{\circ} \mathrm{C}$ prematurely, before full design output power was attained. Data recorded during initial operation showed the radiation panels maintained the rejection temperature at $80{ }^{\circ} \mathrm{C}$ at a power output level of $53 \mathrm{~W}_{\mathrm{e}}$ per convertor. The original radiator panels were 8.5 in. long (fig. 5(a)). These were replaced by panels of the same shape, but $11 \mathrm{in.} \mathrm{long} \mathrm{(fig.} \mathrm{5(b)).} \mathrm{The} \mathrm{larger}$ panels provided a 29 percent increase in radiator area. Analysis was performed to estimate the effect of the added

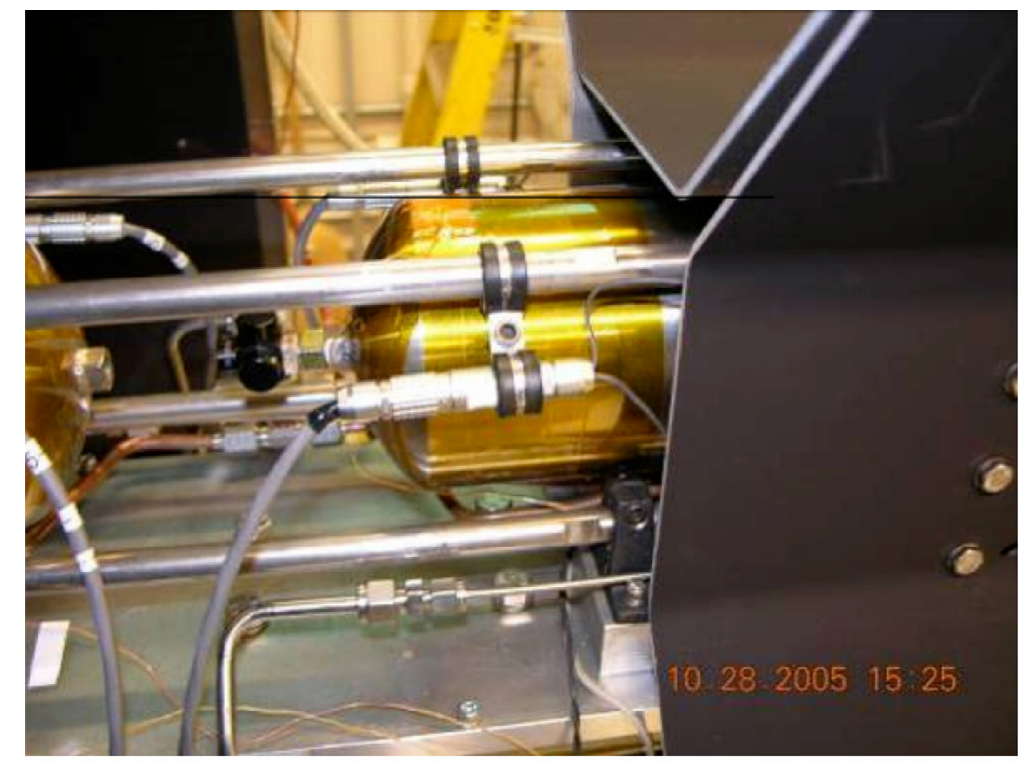

Figure 4.-Maximum pressure vessel Kapton coverage.
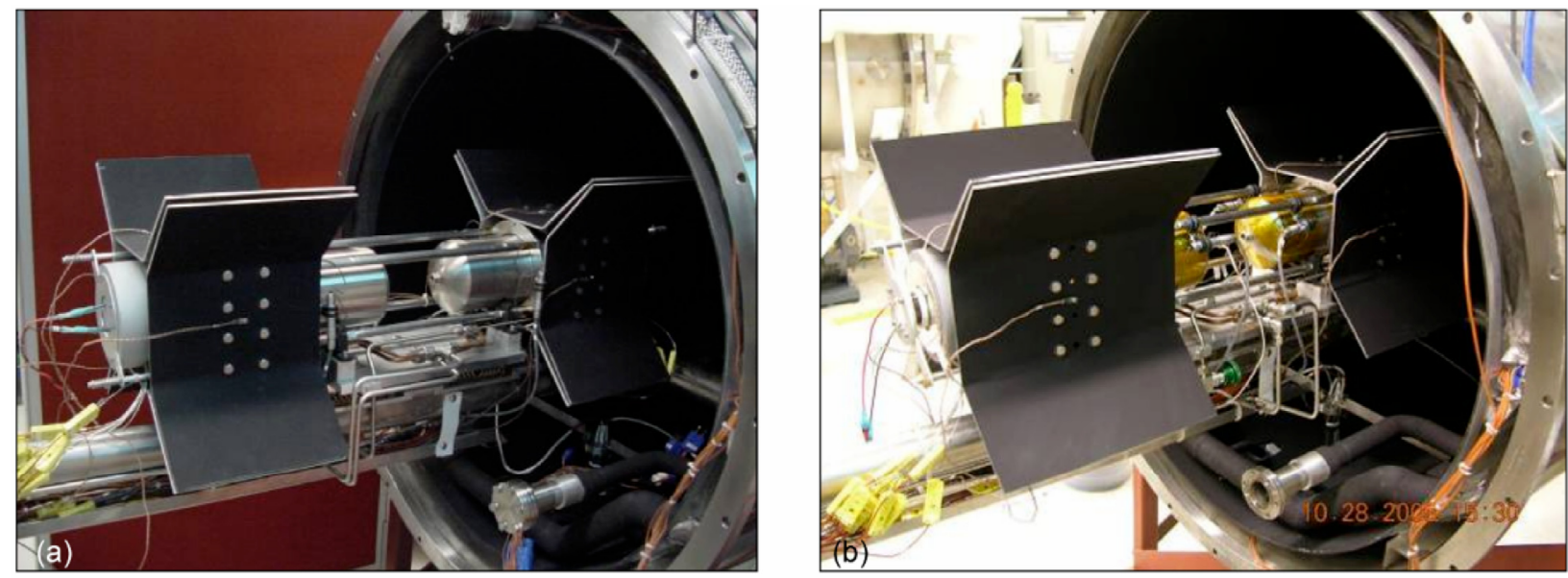

Figure 5.-(a) 8.5-in.-length panels. (b) 11-in.-length panels. 
area before installation. A thermal circuit model of the rejection hardware was constructed based on existing performance data with the shorter set of panels. This model was used to predict rejection temperatures over a range of output power levels with the added panel area. The analysis indicated the larger panels would be capable of maintaining the rejection temperature at $82{ }^{\circ} \mathrm{C}$ at a power output level of $70 \mathrm{~W}_{\mathrm{e}}$ per convertor. After the larger panels were installed, the operating conditions were adjusted to achieve maximum output power by increasing the hot-end temperature. Data recorded at this point showed that the new panels maintained a $70{ }^{\circ} \mathrm{C}$ rejection temperature at $64 \mathrm{~W}_{\mathrm{e}}$ output. This was in accord with the predictions generated by the analysis.

\section{Heater attachment hardware}

The initial test article design utilized molybdenum fasteners for the heater electrical connection and for the backing plate preload. The fasteners functioned properly during the initial checkout up to $575^{\circ} \mathrm{C}$, but lost preload upon return to ambient temperature. Analysis indicated the failure was caused by thermally induced stresses from differing thermal expansion coefficients. The thermal expansion coefficient of the Boralectric heater is approximately 7.4 times that of molybdenum. The heater and fasteners both experienced a temperature change greater than $600^{\circ} \mathrm{C}$. This induced a stress higher than the yield strength of molybdenum at that temperature, resulting in a permanent deformation. The connections were redesigned (rev. 1) to improve their tolerance of the high temperatures. The goal of the new design was to minimize the stiffness of the fastening system thus minimizing the thermally induced stress. This was accomplished by increasing the fastener lengths (fig. 6). Spacers were required to fill in the gaps created by the longer fasteners. The thickness of these spacers was minimized to reduce their stiffness as well. The fasteners and spacers were made of A286 stainless steel. However, design revision 1 did not function as desired. After just $157 \mathrm{hr}$ of operation at an average hot-end temperature of $604{ }^{\circ} \mathrm{C}$, one of the spacers on the TDC 5 heater electrical connection melted. The heater attachment hardware was again redesigned (rev. 2). This revision utilized a spring-loaded electrical lead rather than a threaded fastener to supply electricity to the heater (fig. 7). This enhanced the reliability of the electrical connection during temperature cycles by better accommodating the thermal expansion of the heater. The structure to apply the spring load to the lead was situated outside the insulation to avoid the high-temperature environment. The only component exposed to the high temperature was the lead itself. The spring load of the electrical leads also supplemented the backing plate to hold the heater against the heat collector face. The material of the backing plate was changed from nickel 201 to Inconel 718 for added strength. The material of the backing plate fasteners and spacers was changed from A286 stainless steel to Inconel 718. The spring-loaded electrical connection permitted operation at a maximum hot-end temperature of $650^{\circ} \mathrm{C}$ as desired. At full input power and a $650{ }^{\circ} \mathrm{C}$ maximum hot-end temperature, the Boralectric heater operated at $715^{\circ} \mathrm{C}$. The spring-loaded connection has survived at this condition for over $2800 \mathrm{hr}$.

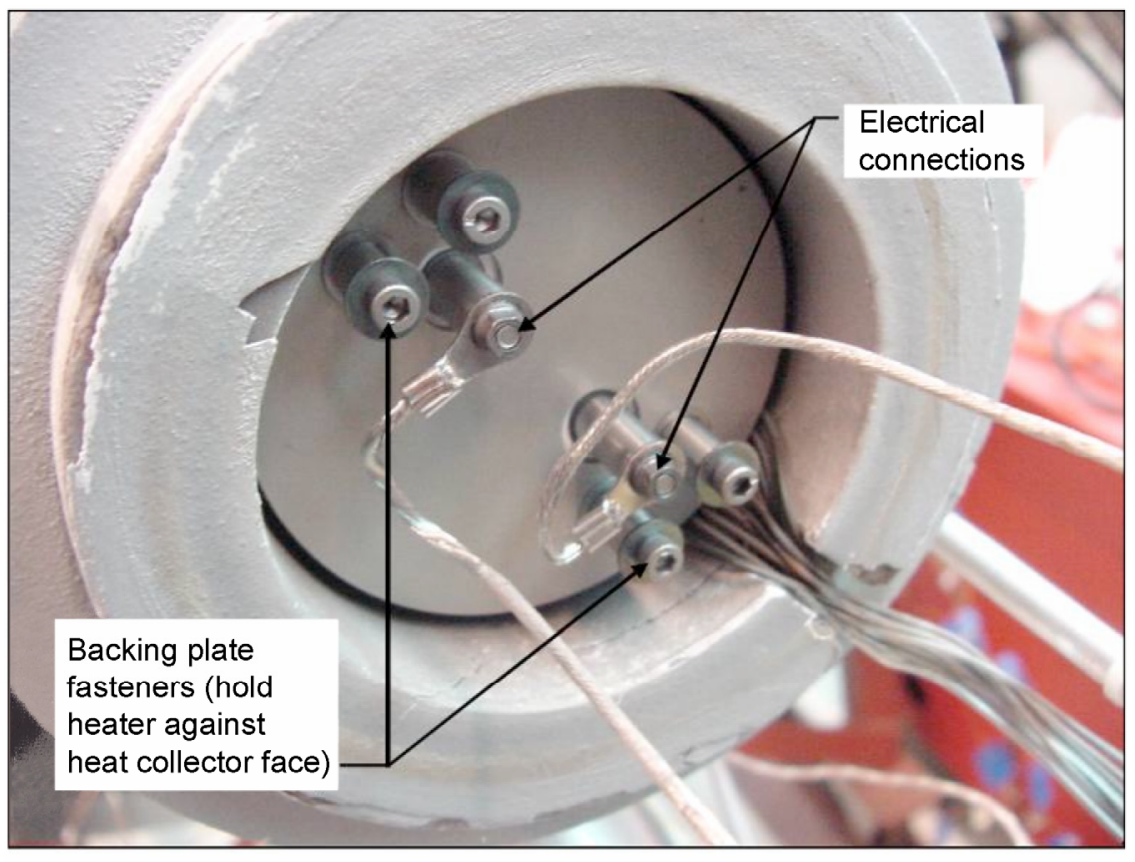

Figure 6.-Hot end fastener design revision 1. 

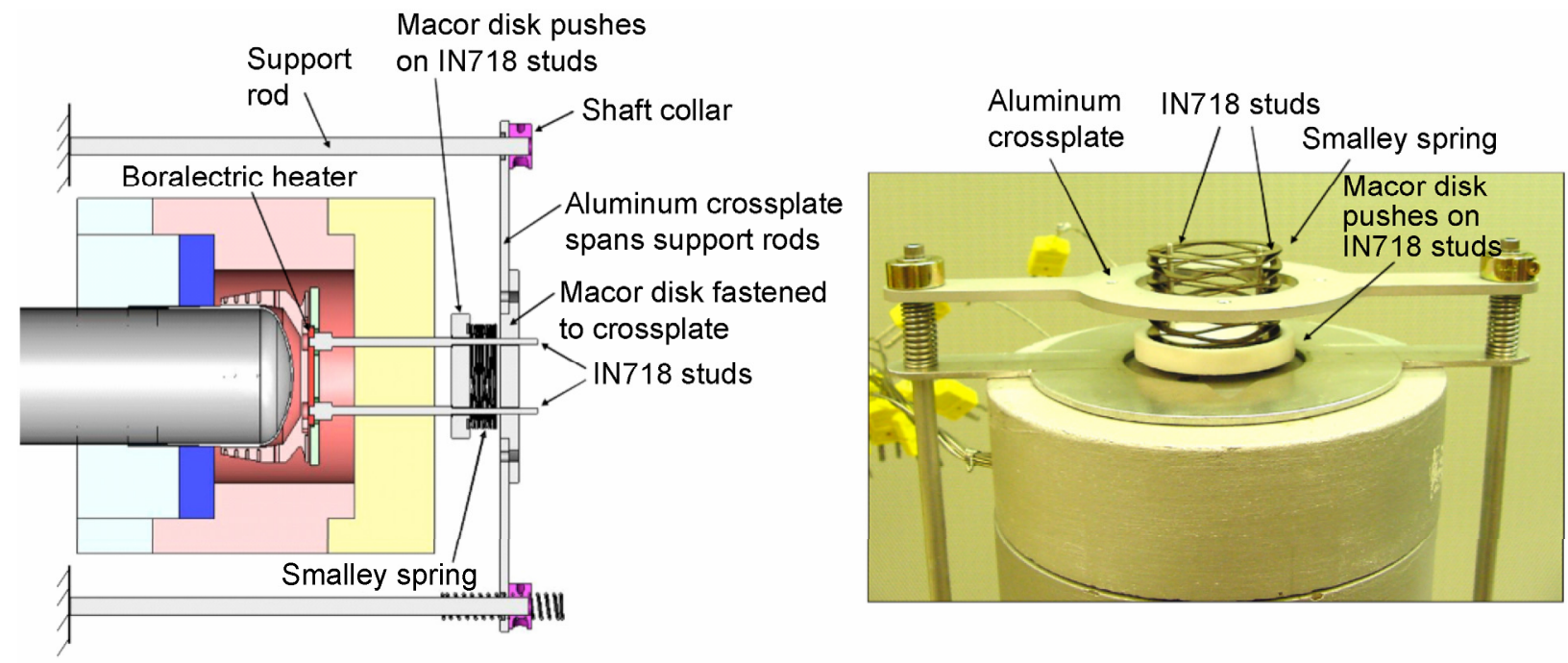

Figure 7.- Hot end fastener design revision 2.

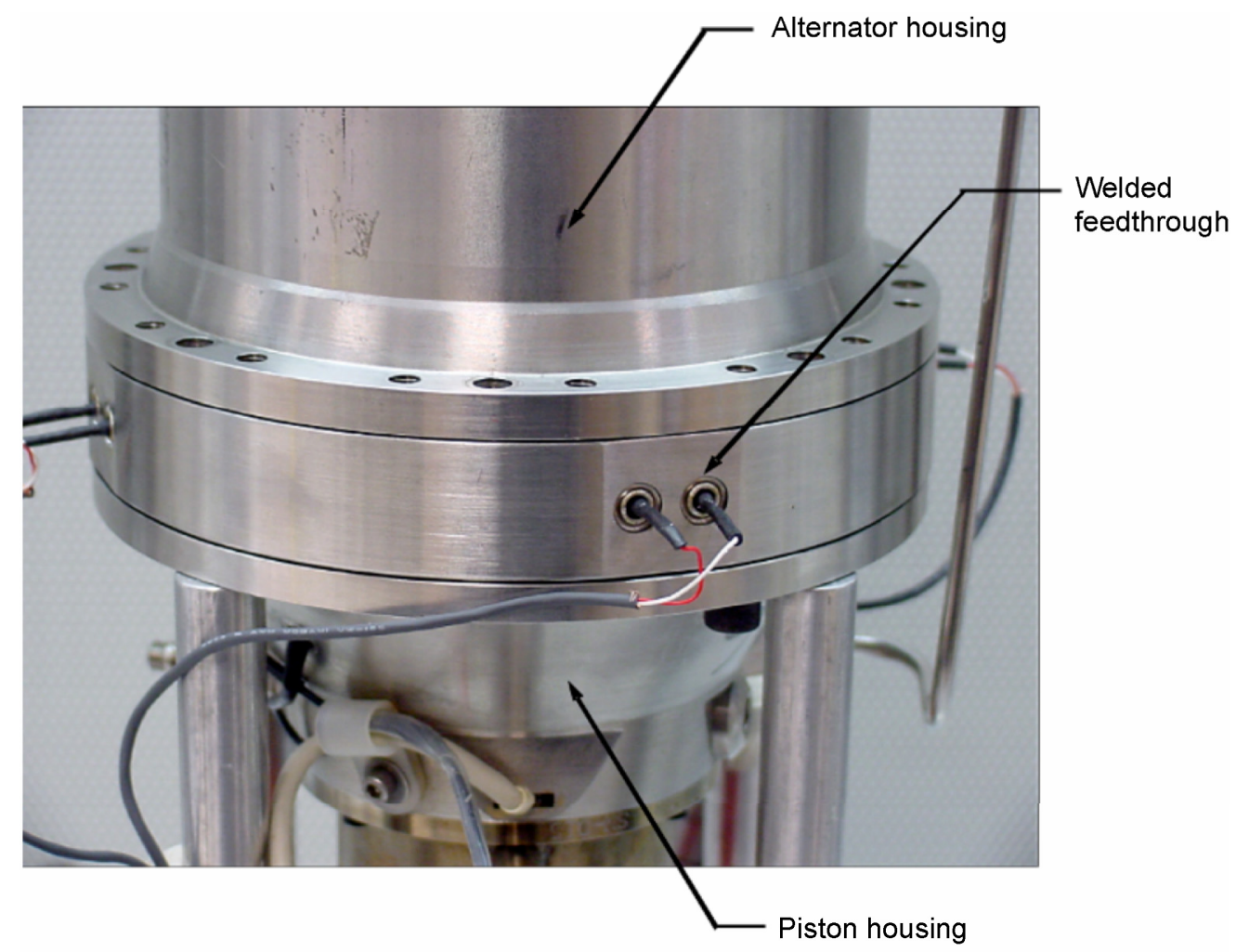

Figure 8.-TDC 5 feedthrough ring.

\section{Helium seals}

Initial extended operation was also disrupted by helium leakage. The charge pressure of TDC 5 dropped about 1.5 psi per day, and was adjusted almost daily. The charge pressure of TDC 6 dropped to about 0.2 psi per day, and was adjusted once per week. The TDCs were not hermetically sealed, and utilized o-rings to seal the helium working fluid at the flange joints. Thus there was some finite leakage that occurred because of permeation or imperfect o-ring compression. An additional leak on TDC 5 was discovered at a faulty weld on the feedthrough ring used to pass the piston position signal through the convertor housing (fig. 8). The faulty feedthrough ring was replaced with a spare and the leak rate was reduced by a factor of 2.4 as shown in table 1 . 
TABLE 1.-TEST ARTICLE HELIUM LEAK RATES

\begin{tabular}{|l|c|c|}
\hline Charge pressure leak rate & TDC 5 & TDC 6 \\
\hline Before hardware mods (psig/day) & -1.51 & -0.21 \\
\hline After hardware mods (psig/day) & -0.62 & -0.34 \\
\hline
\end{tabular}

\section{Extended Operation Performance Data}

Extended operation was initiated in November 2004. The initial operating point was limited to a hot-end temperature of $513{ }^{\circ} \mathrm{C}$ because of the inadequate cooling of the rejection zone and pressure vessel. An attempt was made to operate at a higher hot-end temperature of $604{ }^{\circ} \mathrm{C}$ while simultaneously reducing the piston amplitude to maintain the rejection and pressure vessel temperatures. However, the revision 1 heater electrical connection did not survive more than $157 \mathrm{hr}$ at the higher temperature. This failure is depicted at $1083 \mathrm{hr}$ (label 1) of operation on the performance graphs of figure 9(a) and (b). The heater electrical connection hardware was replaced with spare units,
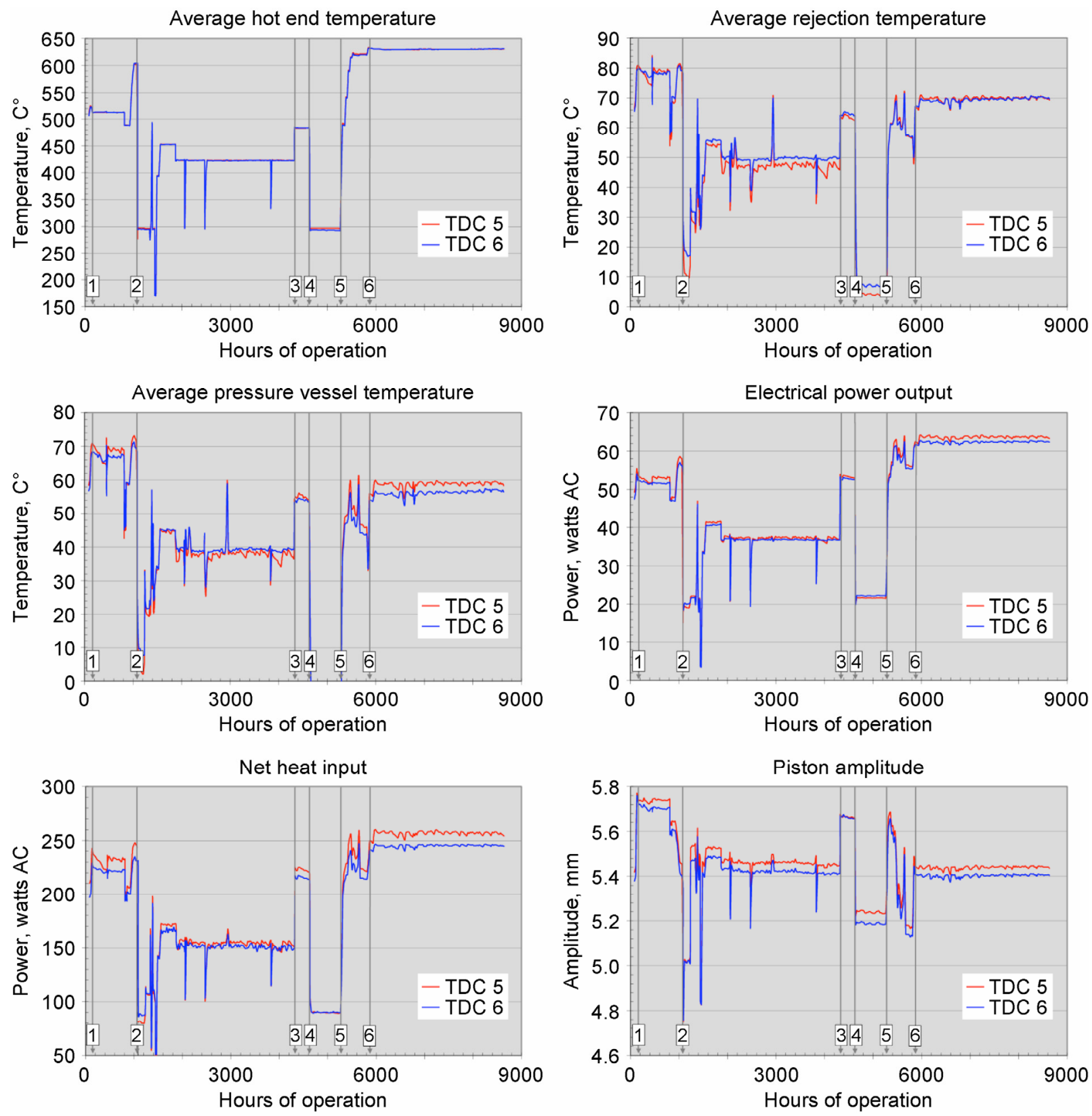

Figure 9.-(a) Extended operation performance data. 

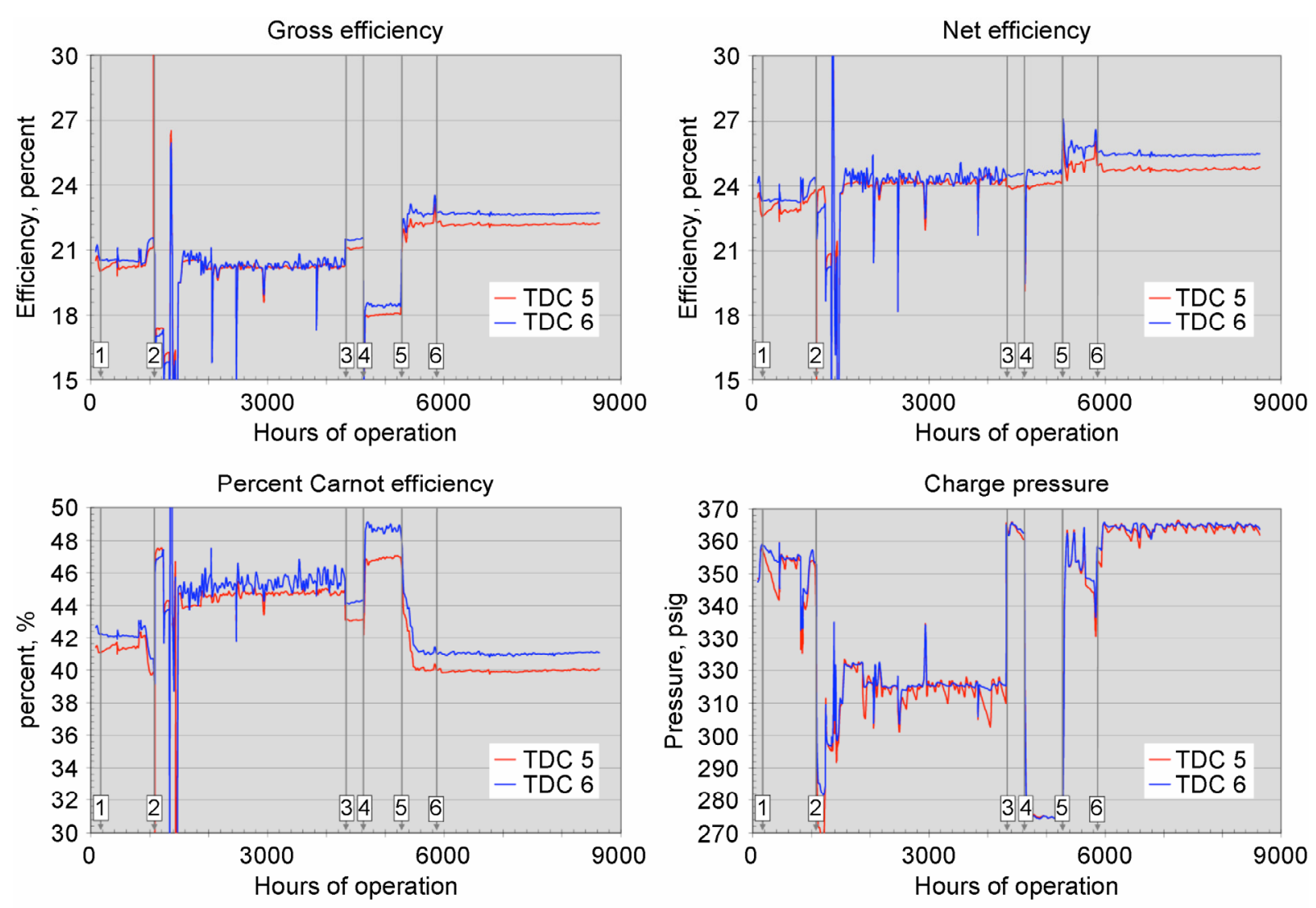

Figure 9.-(b) Extended operation performance data.

and operation resumed at a lower hot-end temperature of $420^{\circ} \mathrm{C}$. This condition continued from 1083 to $4320 \mathrm{hr}$ (label 3) while the revision 2 heater attachment hardware was designed and fabricated. The data between labels 2 and 3 were erratic due to multiple shutdowns related to facility issues such as power outages, vacuum leaks, and $\mathrm{LN}_{2}$ system failures. Data between 4320 and $4637 \mathrm{hr}$ (label 4) depict low-temperature operation after installation of the revision 2 heater hardware, the larger radiation panels, the replacement feedthrough ring, and the pressure vessel Kapton tape. The low-temperature checkout procedure restricted the maximum hot-end temperature to $500{ }^{\circ} \mathrm{C}$ to prevent oxidation of the stainless steel regenerator. This was necessary because TDC 5 was exposed to air during the replacement of the feedthrough ring, and a vacuum bakeout had not yet been performed. Data starting at $4637 \mathrm{hr}$ (label 5) depict post-vacuum bakeout operation at which point it was permissible to operate at a hot-end temperature greater than $500{ }^{\circ} \mathrm{C}$. The hot-end temperature was increased gradually until any hot-end thermocouple read $650{ }^{\circ} \mathrm{C}$. This was achieved at $5842 \mathrm{hr}$ (label 6). While increasing the hot-end temperature, it was necessary to reduce the piston amplitude to maintain the displacer amplitude below its maximum value. Table 2 summarizes the operating conditions attained at $5842 \mathrm{hr}$. Because of the use of a heat collector, an axial temperature gradient existed along the hot-end zone. This is the reason for the difference between average and maximum hot-end temperature. Operation at full output power and a maximum hot-end temperature of $650{ }^{\circ} \mathrm{C}$ yielded an average hot-end temperature of approximately $630{ }^{\circ} \mathrm{C}$. True steady-state operation at the desired operating point was not achieved until after $5842 \mathrm{hr}$ (label 6) of operation. After this point, the operating conditions were maintained at those shown in table 2. As of June 1,2006, the TDCs have accumulated over $2800 \mathrm{hr}$ of operation at these conditions. The fluctuation in power output can be attributed to the fluctuation in charge pressure. The charge pressure was periodically adjusted to maintain its nominal value of $365 \mathrm{psig}$ to compensate for helium leakage. The fluctuating charge pressure also caused fluctuations in the rejection and pressure vessel temperatures since these components rely on passive cooling. The hot-end temperature does not exhibit these fluctuations because it was controlled by a closed proportionalintegral-derivative (PID) loop. The hot-end insulation losses were not measured. On in-air setups, the insulation losses have been characterized by replicating the operating temperatures on a nonoperating convertor and measuring the heat input. On the thermal vacuum setup, the thermal conditions could not be replicated without an operating convertor because of the use of passive temperature control on the rejection and pressure vessel sections. The 
insulation losses in thermal vacuum were estimated using finite element analysis. The analysis indicated that at maximum hot-end temperature the losses total $30 \mathrm{~W}_{\text {th. }}$. This loss was applied as a constant value to all operating conditions. Thus the net heat input equals the measured gross heat input minus $30 \mathrm{~W}_{\text {th }}$ for all data points. The $2800 \mathrm{hr}$ of operation following label 6 are most useful for examining long-term aging effects. The data in this region showed no decay in power or efficiency. A linear curve fit of TDC 5 power output in this region actually has a positive slope of $8 \mathrm{e}-5 \mathrm{~W}_{\mathrm{e}}$ per day. However, more hours are necessary to accurately evaluate the long-term stability of power generation.

TABLE 2.-MAXIMUM OPERATING CONDITIONS ATTAINED

\begin{tabular}{|l|c|c|}
\hline \multicolumn{1}{|c|}{$1 / 17 / 068: 42 \mathrm{AM}$} & TDC 5 & TDC 6 \\
\hline Hot end temperature, ${ }^{\circ} \mathrm{C}$ & 629.8 & 629.6 \\
\hline Rejection temperature, ${ }^{\circ} \mathrm{C}$ & 69.9 & 69.0 \\
\hline Pressure vessel temperature,${ }^{\circ} \mathrm{C}$ & 58.9 & 55.8 \\
\hline Charge pressure, $\mathrm{psig}$ & 363.5 & 364.1 \\
\hline Piston amplitude, $\mathrm{mm}$ & 5.44 & 5.40 \\
\hline Power output, $\mathrm{W}_{\mathrm{e}}$ & 63.6 & 62.2 \\
\hline Cold wall temperature, ${ }^{\circ} \mathrm{C}$ & \multicolumn{2}{|c|}{-168.1} \\
\hline
\end{tabular}

\section{Summary}

An experiment has been initiated at GRC to investigate operation of two Stirling power convertors in a thermal vacuum environment. Performance data gathered thus far has been presented, as well as the difficulties encountered with the supporting hardware. As of June 1, 2006, TDCs 5 and 6 have accumulated over $8700 \mathrm{hr}$ of extended operation in the thermal vacuum configuration. After modifications to the initial support hardware were made, the operating point was adjusted as close as possible to the design point. The actual operating conditions achieved were $630{ }^{\circ} \mathrm{C}$ average hot-end, $70{ }^{\circ} \mathrm{C}$ rejection, $5.45-\mathrm{mm}$ piston amplitude, and $64 \mathrm{~W}_{\mathrm{e}}$ power output.

\section{References}

1. "Stirling Radioisotope Generator for Mars Surface and Deep Space Missions," Robert D. Cockfield and Tak S. Chan, 2002 Intersociety Energy Conversion Engineering Conference, Washington, DC, Paper No. 20188.

2. "Stirling Convertor Performance Mapping and Test Results for Future Radioisotope Power Systems," Songgang Qiu and Allen A. Peterson, 2003 International Energy Conversion Engineering Conference, Porthmouth, VA.

3. "Extended Operation of Stirling Convertors," Mary Ellen Roth, Jeffrey G. Schreiber, and Stephen V. Pepper, 2004 Second International Energy Conversion Engineering Conference, Providence, RI, Paper No. AIAA 2004-5508. 


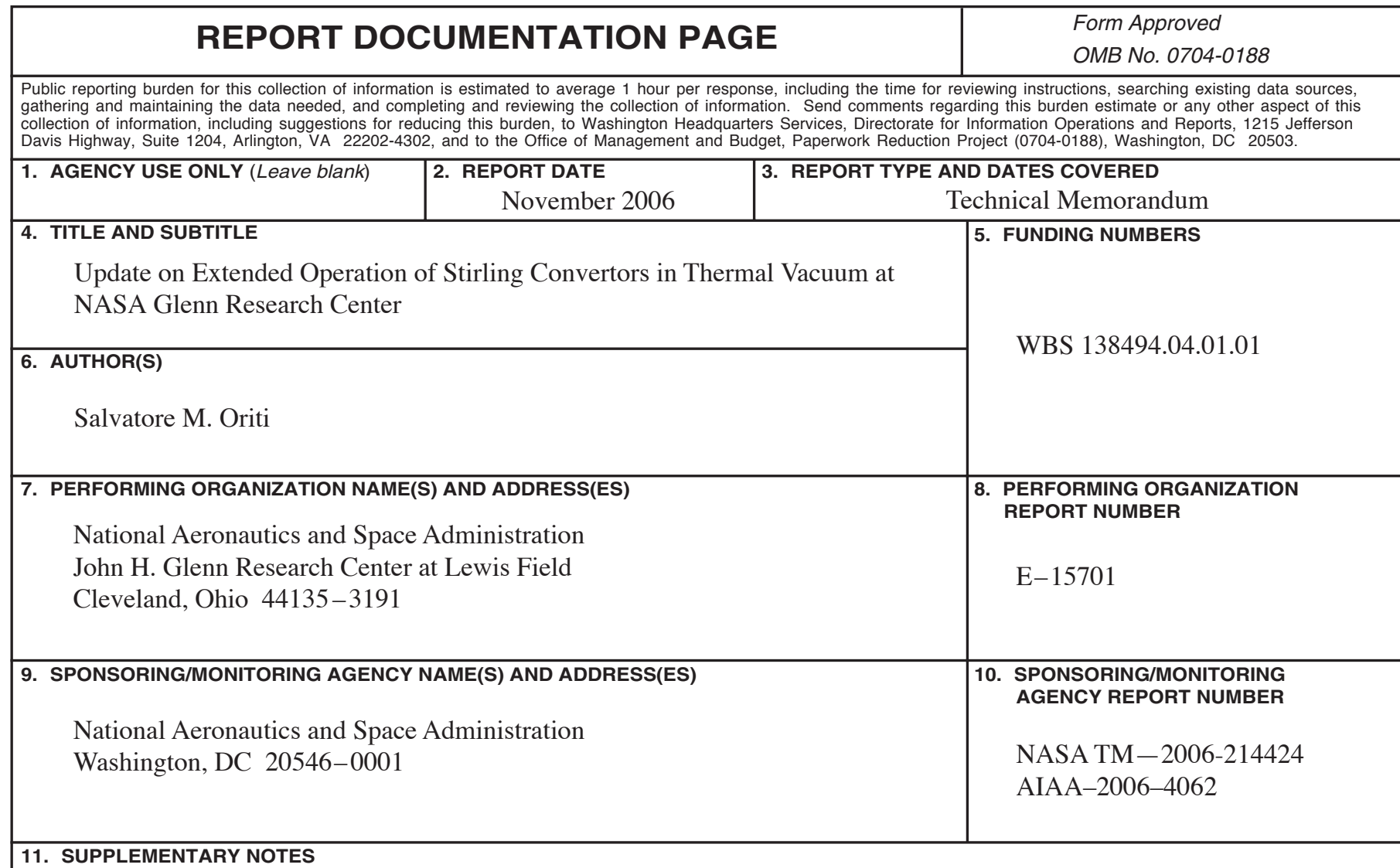

Prepared for the Fourth International Energy Conversion Engineering Conference and Exhibit (IECEC) sponsored by the American Institute of Aeronautics and Astronautics, San Diego, California, June 26-29, 2006. Responsible person,

Salvatore M. Oriti, organization code RPT, 216-433-2066.

\begin{tabular}{|l|l|l|l|l}
\hline 12a. DISTRIBUTION/AVAILABILITY STATEMENT & 12b. DISTRIBUTION CODE
\end{tabular}

Unclassified - Unlimited

Subject Category: 20 or

Available electronically at http://gltrs.grc.nasa.gov

This publication is available from the NASA Center for AeroSpace Information, 301-621-0390.

13. ABSTRACT (Maximum 200 words)

The U.S. Department of Energy (DOE), Lockheed Martin Space Systems (LMSS), Infinia Corporation, and NASA Glenn Research Center (GRC) have been developing a Stirling Radioisotope Generator (SRG) for use as a power system on space science missions. This generator would make use of Stirling cycle energy conversion to achieve higher efficiency than currently used alternatives. A test has been initiated at GRC to demonstrate functionality of Stirling conversion in a thermal vacuum environment over an extended period of time. The test article resembles the configuration of the SRG, but was designed without the requirement of low mass. Throughout the 8700 cumulative hours of operation, modifications to the supporting hardware were required to attain the desired operating conditions. These modifications, the status of testing, and the data recorded will be discussed in this paper.

\begin{tabular}{|c|c|c|c|}
\hline \multicolumn{3}{|l|}{ 14. SUBJECT TERMS } & 15. NUMBER OF PAGES \\
\hline \multicolumn{3}{|c|}{ Stirling; SRG; Radioisotope; Thermal vacuum } & $\begin{array}{r}15 \\
\text { 16. PRICE CODE }\end{array}$ \\
\hline $\begin{array}{l}\text { 17. SECURITY CLASSIFICATION } \\
\text { OF REPORT }\end{array}$ & $\begin{array}{l}\text { 18. SECURITY CLASSIFICATION } \\
\text { OF THIS PAGE }\end{array}$ & $\begin{array}{l}\text { 19. SECURITY CLASSIFICATION } \\
\text { OF ABSTRACT }\end{array}$ & 20. LIMITATION OF ABSTRACT \\
\hline Unclassified & Unclassified & Unclassified & \\
\hline
\end{tabular}



